\title{
Western Bean Cutworm Survival and the Development of Economic Injury Levels and Economic Thresholds in Field Corn
}

Author(s): S. Paula-Moraes, T. E. Hunt, R. J. Wright, G. L. Hein, and E. E. Blankenship

Source: Journal of Economic Entomology, 106(3):1274-1285. 2013.

Published By: Entomological Society of America

URL: http://www.bioone.org/doi/full/10.1603/EC12436

BioOne (www.bioone.org) is a nonprofit, online aggregation of core research in the biological, ecological, and environmental sciences. BioOne provides a sustainable online platform for over 170 journals and books published by nonprofit societies, associations, museums, institutions, and presses.

Your use of this PDF, the BioOne Web site, and all posted and associated content indicates your acceptance of BioOne's Terms of Use, available at www.bioone.org/page/terms of use.

Usage of BioOne content is strictly limited to personal, educational, and non-commercial use. Commercial inquiries or rights and permissions requests should be directed to the individual publisher as copyright holder. 


\title{
Western Bean Cutworm Survival and the Development of Economic Injury Levels and Economic Thresholds in Field Corn
}

\author{
S. PAULA-MORAES, ${ }^{1}$ T. E. HUNT, ${ }^{2}$ R. J. WRIGHT, ${ }^{3}$ G. L. HEIN,${ }^{4}$ and E. E. BLANKENSHIP ${ }^{5}$
}

\begin{abstract}
J. Econ. Entomol. 106(3): 1274-1285 (2013); DOI: http://dx.doi.org/10.1603/EC12436
ABSTRACT Western bean cutworm, Striacosta albicosta (Smith) (Lepidoptera: Noctuidae), is a native pest of dry beans (Phaseolus vulgaris L.) and corn (Zea mays L.). Historically, the western bean cutworm was distributed in the western United States, but since 1999 eastward expansion has been observed. In corn, economic impact is caused by larval ear feeding. Information on western bean cutworm biology, ecology, and economic impact is relatively limited, and the development of economic injury levels (EILs) and economic thresholds (ETs) is required for more effective management. Studies during 2008-2011, across three ecoregions of Nebraska, sought to characterize western bean cutworm survival and development of EILs and ETs. Calculations of EILs and ETs incorporated the dynamics of corn price, management cost, and pest survival. The results from the current study demonstrated low larval survival of this species (1.51-12.82\%). The mean yield loss from one western bean cutworm larva per plant was $945.52 \mathrm{~kg} / \mathrm{ha}$ ( $15.08 \mathrm{bu} / \mathrm{acre})$, based on 74,100 plants per ha. Economic thresholds are expressed as a percentage of plants with at least one egg mass. This study is the first study that explicitly incorporates variable management costs and crop values into western bean cutworm EIL calculations, and larval survival into ET calculations.
\end{abstract}

KEY WORDS Striacosta albicosta, western bean cutworm, larval survival, economic injury level, economic threshold

Western bean cutworm, Striacosta albicosta (Smith) (Lepidoptera: Noctuidae), is a pest of beans (Phaseolus vulgaris $\mathrm{L}$.) and corn (Zea mays L.) (Blickenstaff and Jolley 1982), and it is historically distributed in the western United States (Douglass et al. 1957, Hagen 1976, Blickenstaff 1979). The insect's expansion eastward is documented beginning in 1999 (O'Rourke and Hutchison 2000, Dorhout and Rice 2004, Rice 2006, Cullen and Jyuotika 2008, DiFonzo and Hammond 2008, Michel et al. 2010, Tooker and Fleischer 2010), and it has since been reported in 11 states and provinces (Michel et al. 2010).

Western bean cutworm is univoltine (Hagen 1962, Seymour et al. 2004). In Nebraska, the adults typically emerge in July (Hagen 1976) and lay eggs on corn leaves, with preference for plants in the late-whorl stages (Hagen 1962, Blickenstaff 1979, Holtzer 1983,

\footnotetext{
Mention of a proprietary product does not constitute an endorsement or a recommendation for its use by the universities associated with this research.

${ }^{1}$ Corresponding author: Embrapa Cerrados, BR $020 \mathrm{Km}$ 18, Planaltina,DF, Brazil,73310-970 (e-mail: silvana.moraes@huskers. unl.edu).

2 Department of Entomology, University of Nebraska-Lincoln, NEREC Haskell Agricultural Laboratory, 57905866 Rd., Concord, NE 68728 .

${ }^{3}$ Department of Entomology, University of Nebraska-Lincoln, Lincoln, NE 68583

${ }^{4}$ Doctor of Plant Health Program, University of Nebraska-Lincoln, Lincoln, NE 68583.

${ }^{5}$ Department of Statistics, University of Nebraska-Lincoln, Lincoln, NE 68583 .
}

Seymour et al. 2004, Eichenseer et al. 2008). When the eggs hatch, the larvae feed on different corn tissues, and by the fourth instar, they colonize the ear where they feed on kernels (Appel et al. 1993, Seymour et al. 2004).

Information of western bean cutworm biology, ecology, and economic impact is relatively limited. Hagen (1962) reported ear injury from western bean cutworm ranging from 4 to $40 \%$. Catangui and Berg (2006) reported $7.45-\mathrm{cm}^{2}$ ear injury per larva in several Bacillus thuringiensis (Bt) corn hybrids. Appel (1991) estimated yield loss based on the number and weight of injured kernels, and several nominal action thresholds for field and sweet corn have been proposed $(4,8$, and $20 \%$ of plants infested with an egg mass), roughly based on corn stage and price of the corn (Seymour et al. 2004, Peairs 2006, Rice 2007, Cullen and Jyuotika 2008). Because current thresholds are rudimentary, it is necessary to develop economic injury levels (EILs) and economic thresholds (ETs) for western bean cutworm based on more current understandings of pest injury and damage, dynamic costs of control and corn market values, and pest biology (Pedigo and Rice 2009). The EIL is the lowest density of the pest population that causes economic damage (Stern et al. 1959). The ET represents the population level at which the pest needs to be managed to prevent the population from reaching the EIL (Stern et al. 1959). This parameter is usually set lower than the EIL (Pedigo and Rice 2009) and can be 
expressed for life stages of the pest before the damaging stage for which the EIL was determined.

Foliar insecticides are typically used to control western bean cutworm, and their efficacies are compromised after the larvae enter the ear. Thus, ETs expressed as the percentage of plants infested with egg masses (Appel et al. 1993, Seymour et al. 2004, PaulaMoraes et al. 2011) that also incorporate larval survival (Ostlie and Pedigo 1987, Barrigossi et al. 2003) would present an improvement in management decision making. The incorporation of the variability of larval survival under different environmental conditions would make it possible to more accurately estimate the resultant pest density.

Hence, the objectives of this study were to estimate egg and larval survival of western bean cutworm as measured across three major ecoregions (Level III) (Chapman et al. 2001) in Nebraska, to determine larval injury capacity, and to develop EILs and ETs that incorporate variable larval survival and varying corn prices and management costs.

\section{Materials and Methods}

Studies of western bean cutworm egg survival, larval survival, and larval corn consumption, and yield impact were conducted from 2008 to 2011 at University of Nebraska facilities across three ecoregions (Chapman et al. 2001): Northeast Research and Extension Center Haskell Agricultural Laboratory, Concord (Western Corn Belt Plains); South Central Agricultural Laboratory, Clay Center (Central Great Plains); and Panhandle Research and Extension Center, Scottsbluff (Western High Plains). The corn hybrid DKC 61-72 RR expressing Bt protein CrylAb (YieldGard, Monsanto, St. Louis, MO) that is not toxic to western bean cutworm (Catangui and Berg 2006) was used to minimize the confounding effect of European corn borer [Ostrinia nubilalis (Hübner)] in Clay Center and Concord. In Scottsbluff, due to absence of a European corn borer effect, the corn hybrid was non-Bt (2008, DKC51-45; 2009, Pioneer 35F37; and 2010, Mycogen 2R416).

Based on these studies, EILs were calculated and expressed as larval density. Because western bean cutworm sampling is most effective in establishing the presence of egg masses (Paula-Moraes et al. 2011), the ETs incorporated variable larval survival and were expressed as percentage of plants infested with egg masses.

Egg Survivorship and Developmental Time in Laboratory. Western bean cutworm egg developmental time and survival were evaluated at 16,25 , and $30^{\circ} \mathrm{C}$. One-day-old egg masses were collected from oviposition cages, placed in cotton-lined petri dishes covered to maintain humidity, and incubated in growth chambers. There were three replications at each temperature. Temperatures were randomly assigned to growth chambers in a complete randomized design (total of nine chambers). Eggs totaled 955 at $16^{\circ} \mathrm{C}, 437$ at $25^{\circ} \mathrm{C}$, and 462 at $30^{\circ} \mathrm{C}$. Eggs were monitored every day for $14 \mathrm{~d}$, and the day of hatch was recorded. Egg survival at different temperatures and the linear relationship between temperature and time of development was determined (PROC GLIMMIX, SAS Institute 2009).

Egg Survivorship in Field. Western bean cutworm egg hatch was evaluated at the Northeast Research and Extension Center Haskell Agricultural Laboratory during 2008 and at the South Central Agricultural Laboratory during 2008 and 2011. In 2008, the experimental design was a randomized complete block design (RCBD) with four replications. Each plot was six rows by $12 \mathrm{ft}$ long, with 100 plants in total per plot. Treatment plots were infested with western bean cutworm egg masses at rates of $0,1,3,5$, or $10 \%$. Infestations were artificial, using western bean cutworm egg masses collected from commercial fields. A small square of vinyl screen was stapled loosely behind the egg mass forming a "sandwich" to keep the leaf from curling and dislodging egg masses. The leaf sandwich was stapled to the upper surface of a corn leaf above the primary ear. The infested plants were identified by tying flagging tape at the base of the plant. To minimize injury to the eggs, the number of eggs per egg mass was determined by photographing each egg mass and counting the eggs in the laboratory before plant infestation. The total number of eggs infested at Concord was 4,037, and at Clay Center was 3,927. At 2 wk after infestation, the sandwiches were removed from the field and examined with microscopy to record the number of unhatched eggs. The percentage of eggs hatched was calculated. Temperature data during egg incubation at Concord (24-31 July 2008) and at Clay Center (28 July 2008-4 August 2008) were obtained from the High Plains Region Climate Center (http:/ / hprcc.unl.edu).

At Clay Center during 2011, western bean cutworm egg hatch was evaluated in two corn fields at different corn development stages: VT and silking (Ritchie et al. 1993). In each corn field, the infestation was one egg mass per plot, and plots were $15 \mathrm{ft}$ long by four rows wide, with 25 plants per row ( 100 plants per plot). The infestation was artificial but used naturally oviposited egg masses (Paula-Moraes 2012). Western bean cutworm moths were captured in cages positioned under UV light traps. One male and two female moths were confined on the top part of a corn plant with a mesh pollination bag (46 by $51 \mathrm{~cm}$ ) (Delnet Pollination Bags, Delnet, Middletown, DE). Two days after infestation, the presence of egg masses was determined and thinned, when necessary, so only one egg mass was left per plant. The number of eggs in each egg mass was determined by photographing the egg masses for later counting. The few plants on which the western bean cutworm females did not lay egg masses were artificially infested following the same egg mass sandwich method. The percentage of eggs hatching was calculated for each corn stage. Temperature data during egg incubation in Clay Center (21-28 July 2011) were obtained from the High Plains Region Climate Center (http:/ / hprcc.unl.edu). Egg infestation methods (egg mass sandwich versus moths in pollination bags) were compared for silking and VT stages. 
Table 1. Experimental design of larval survival, consumption, and yield impact at three field locations of Nebraska

\begin{tabular}{|c|c|c|c|c|c|c|}
\hline Location & $\begin{array}{l}\text { Egg mass } \\
\text { infestation } \\
\text { levels }(\%)\end{array}$ & $\begin{array}{l}\text { Infestation } \\
\text { methodology }\end{array}$ & $\begin{array}{l}\text { Corn stage at } \\
\text { infestation }\end{array}$ & $\begin{array}{l}\text { Plant position of egg } \\
\text { mass }\end{array}$ & $\begin{array}{c}\text { Larval survival } \\
\text { evaluation } \\
\text { (plants per plot) }^{a}\end{array}$ & $\begin{array}{l}\text { Ear injury and } \\
\text { yield evaluation } \\
\text { (plants per plot) }\end{array}$ \\
\hline \multicolumn{7}{|l|}{2008} \\
\hline Clay Center & $0,1,3,5,10$ & Egg mass sandwich & Blister & Above primary ear & 30 & 70 \\
\hline Concord & $0,1,3,5,10$ & Egg mass sandwich & Silk & Above primary ear & 30 & 70 \\
\hline Scottsbluff & $0,1,3,5,10$ & $\begin{array}{l}\text { Large cages, egg } \\
\text { mass sandwich }\end{array}$ & V18 & $\begin{array}{l}\text { Natural deposition and } \\
\text { top of the plant }\end{array}$ & 30 & 70 \\
\hline \multicolumn{7}{|l|}{2009} \\
\hline Clay Center & $0,1,3,5,7,10$ & Egg mass sandwich & Silk & Above primary ear & 30 & 70 \\
\hline Concord & $0,1,3,5,7,10$ & Egg mass sandwich & Blister & Above primary ear & 30 & 70 \\
\hline Scottsbluff & $0,1,3,5,10$ & $\begin{array}{l}\text { Large cages, egg } \\
\text { mass sandwich }\end{array}$ & V18 & $\begin{array}{l}\text { Natural deposition and } \\
\text { top of the plant }\end{array}$ & 30 & 70 \\
\hline \multicolumn{7}{|l|}{2010} \\
\hline Clay Center & $0,1,3,5,7,10$ & $\begin{array}{l}\text { Pollination bag, egg } \\
\text { mass sandwich }\end{array}$ & V18 & Top of the plant & 50 & 50 \\
\hline Concord & $0,1,3,5,7,10$ & $\begin{array}{l}\text { Pollination bag, egg } \\
\text { mass sandwich }\end{array}$ & V18 & Top of the plant & 100 & 100 \\
\hline
\end{tabular}

${ }^{a}$ Larval survival evaluation $\approx 20 \mathrm{~d}$ after egg infestation.

An overall mean number of eggs per egg mass was calculated based on the 714 egg mass pictures. These egg masses included those from confined moths inside pollination bags and large cages, but they were predominantly from commercial fields collected from several ecoregions in Nebraska and eastern Colorado during the 4 yr of study.

Larval Survivorship in Field. Evaluations were conducted at three locations across Nebraska: Northeast Research and Extension Center Haskell Agricultural Laboratory, South Central Agricultural Laboratory, and Panhandle Research and Extension Center. At Concord and Clay Center, the larval evaluation was conducted during 2008-2010. A RCBD was used with four replications. Details are presented in Table 1. Natural infestation of western bean cutworm in experimental plots was monitored. At Clay Center and Concord, plants were inspected for the presence of western bean cutworm egg masses before artificial infestation. Natural infestation was extremely low during 2008-2009 at both locations. At Scottsbluff, larval survival evaluation was conducted during 2008 and 2009. Natural infestation inspections were done after the large plot cages were installed in the experimental plots. Egg masses from natural infestation were eliminated from all experimental plots.

In 2008, larval survival at Clay Center and Concord was evaluated in the same experimental plots where the egg hatch was evaluated. Approximately $20 \mathrm{~d}$ after western bean cutworm egg infestation, the number of the larvae was estimated based on the evaluation of 30 randomly selected plants per plot (Table 1). In 2009 (Clay Center and Concord), larval survival was evaluated following the same methodology of 2008. The plots were infested by using the egg mass sandwich method at rates of $0,1,3,5$, and $10 \%$ (Table 1 ).

In 2010, larval survival was evaluated in Clay Center and Concord $\approx 20 \mathrm{~d}$ after western bean cutworm egg mass infestation. Infestations were done using the pollination bag or sandwich method described earlier at rates of $0,1,3,5,7$, and $10 \%$. At Concord, three additional plots per block were infested for use in larval sampling. Two additional plots were infested at the $3 \%$ egg mass level. One plot was infested using egg mass sandwich method, whereas the other was infested with wild moths confined in pollination bags. One additional plot was infested at the $10 \%$ level by using the pollination bag method. Larval survival was evaluated at Concord in the three extra plots per block, and all 100 plants per plot were inspected for the presence of western bean cutworm larvae. At Clay Center, larval survival was determined in all plots, inspecting 50 plants per plot, and the number of larvae per plot was estimated based on this sample (Table 1).

During the $2 \mathrm{yr}$ of the study at Scottsbluff, the artificial infestation was done by placing a 1.83 by 1.83 by $2.45-\mathrm{m}$ cage over a central part of the plot and introducing moths for oviposition. A variable number of moths was introduced into each cage based on the target egg mass infestation level, and later egg mass density was determined. Egg masses were thinned, if necessary. One extra plot was artificially infested at 3\% by using the sandwich method. Twenty days after infestation, the number of western bean cutworm larvae was evaluated on 30 randomly selected plants in each plot (Table 1).

The number of recovered larvae was correlated with the number of infested eggs, and percentage of larval survival was calculated. The effect of method of infestation (egg mass sandwich vs wild moths in big cages) for larval survival was tested at Scottsbluff by using analysis of variance (ANOVA) (2008 and 2009 data) (PROC GLIMMIX, SAS Institute 2009).

Larval Corn Consumption and Yield Impact in Field. Larval consumption and the relationship among western bean cutworm infestation, corn ear injury, and yield was characterized at the same three locations and experimental plots described previously. From 2008 to 2010 (Table 1), at harvest, the amount of injury (square centimeters of grain surface with western bean cutworm injury per ear) was measured using a transparent plastic sheet with grid lines. Total injury was measured considering tip and side ear in- 
jury. The grain yield and moisture also were determined.

The number of corn ears evaluated varied each year (Table 1). In 2008 and 2009, $\approx 70$ plants remained after the larval survival evaluation. At Clay Center in 2010, western bean cutworm survival was determined without destruction of the ear in the two central rows of the plot (50 plants). At harvest, injury was evaluated in the same corn ears. At Concord in 2010, the larval survival was evaluated with destructive sampling in three plots per block. The other remaining six plots (100 plants per plot) were hand harvested, and injury was evaluated. At Scottsbluff during 2008 and 2009, 70 corn ears per plot were evaluated (Table 1). For all locations and years of study, the total weight of the grain was determined in each plot, corrected to $15.5 \%$ moisture content, and data were converted to a per ear basis.

In 2011, at Concord and Clay Center, direct corn ear infestation was done with fourth instar larva (the instar that larva enters the ear). Larvae were reared on a meridic diet specifically developed for western bean cutworm and obtained from the USDA-ARS, Corn Insects and Crop Genetics Research Unit, Iowa State University, Ames, IA. The study was conducted in two fields at each location infested on the same date. At each location, one field was infested when the corn was at blister stage, and the other field infested when the corn was at milk stage (Ritchie et al. 1993). The experimental area in each field was eight rows by $70 \mathrm{~m}$. Four treatments (zero, one, two, or three larvae per ear) were used in a RCBD, with 20 replications. Each plot was one row by $3.5 \mathrm{~m}$, and within each plot two plants (ears) were randomly selected and infested.

The larvae were confined to the corn ear with mesh pollination bags $(25$ by $30 \mathrm{~cm}$ ). Inspection for larval survival was done approximately 1 mo after larval infestation. The presence of the western bean cutworm prepupa and injury were examined to confirm the level of infestation per ear. At harvest, corn ears were hand harvested, the injury area was measured, ear grain was shelled and weighed, and moisture was corrected to $15.5 \%$.

Generalized linear mixed model procedures were used to determine the linear relationship between injury area and number of western bean cutworm larvae. The additional random effects were used to inform that experimental unit was two plants infested with the same number of larvae. The linear relationship between corn grain and number of larvae (PROC GLIMMIX, SAS Institute 2009) also was determined. For the 2011 data, the correlation between observed value and predicted value of ear weight was calculated (PROC CORR, SAS Institute 2009). An overall mean of larval injury area also was calculated (PROC GLIMMIX, SAS Institute 2009).

Larval Corn Consumption in Laboratory. Western bean cutworm larval consumption also was evaluated in the laboratory at the Northeast Research and Extension Center Haskell Agricultural Laboratory. The experiment was performed in 2009 and 2011 with blister and milk stage corn at the time of infestation. Injury area (square centimeters of grain surface) caused from the beginning of fourth instar to end of fifth instar was recorded.

In 2009, the study was conducted as a RCBD, with three replications (replication by growth chamber) set at $25^{\circ} \mathrm{C}$. Five small circular containers $(10-\mathrm{cm}$ diameter and 4-cm height) per corn stage (blister and milk) were placed in each growth chamber, each container with one half a corn ear without the husk. The corn ear was placed on a layer of sand (Paula-Moraes, 2012). Another methodology was tested using a larger circular container $(30-\mathrm{cm}$ diameter and $7.6-\mathrm{cm}$ height) that received a whole corn ear in milk stage (Paula-Moraes, 2012). Western bean cutworm larvae were reared on corn pollen and silk, and one larva was placed on the ear at the beginning of the fourth instar. After $\approx 20 \mathrm{~d}$, the injury area was measured in square centimeters of grain consumed per corn ear. In 2011, the study was similarly conducted, except each growth chamber received 10 large circular containers with one ear at blister stage. After $20 \mathrm{~d}$, the injury area was measured.

The mean injury area was calculated for each corn stage (2009 and 2011) and the effect of corn stage on area injured was compared (2009). The methods were compared using ANOVA (PROC GLIMMIX, SAS Institute 2009).

EILs and Thresholds. EILs and economic thresholds were calculated based on the results from experiments described previously. The EIL was calculated with the formula injury (Pedigo et al. 1986, Pedigo and Rice 2009):

$$
\mathrm{EIL}=\mathrm{C} /[(\mathrm{ID})(\mathrm{V})(\mathrm{K})]
$$

where $\mathrm{C}$ is cost of management per area (e.g., US\$/ ha), V is market value per unit of produce (e.g., US \$ / ha), ID is yield loss per insect (weight of grain loss in kilograms per western bean cutworm larvae), and $\mathrm{K}$ is proportionate reduction in potential.

The cost of management was calculated based on the total expense of chemical control of western bean cutworm (Klein and Wilson 2012) and included the range of control cost variation considering aerial application, ground application, and insecticide expense.

The crop value of corn was calculated based on the price and yield. The price was related to corn grain monthly average of the price received as measured in US \$ bu by the states of Illinois, Indiana, Iowa, Kansas, Michigan, Minnesota, Missouri, and Nebraska (USDA, http://quickstats.nass.usda.gov/, 2012). The period was from January 2000 to December 2011. These nominal prices were converted to real prices using PPI-PRODUCER PRICE INDEX (Federal Reserve Economic Data, base December 2011) and reflect scenarios of low, medium and high corn price. The crop value range was calculated by multiplying the selected higher, lower, and real average of corn prices times the average yield. The yield refers to an average yield of 13,629.26 kg/ha (Klein and Wilson 2012). The yield was calculated based on a conversion of 220 $\mathrm{bu} / \mathrm{acre}$ and on having 30,000 plants per acre $(74,100$ plants per ha). 


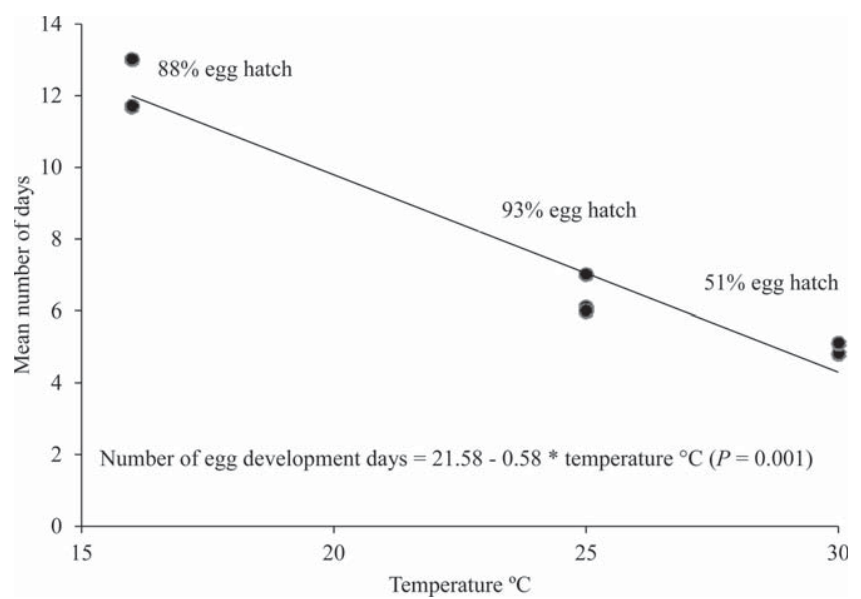

Fig. 1. Western bean cutworm egg developmental time and mean egg hatch at different temperatures.

The yield loss/insect (DI) was obtained from the relationship between corn yield and the number of western bean cutworm larvae (Bode and Calvin 1990, Pedigo and Rice 2009) considering the linear regression equations from 2011 (see Table 5). The worstcase scenario of yield loss was selected and used for EIL calculations to reduce farmer risk. The calculation of grain reduction (grams) per corn ear was based on one larva per plant and was converted to kilograms. The $\mathrm{K}$ was set at $95 \%$ and represents the expected proportion of the population of western bean cutworm larvae killed by chemical control (Peairs et al. 2011).

The ET was calculated as an operational level for management decision making. The mean numbers of eggs per egg mass and larval survival were incorporated in the ET calculations (Ostlie and Pedigo 1987, Wright 2007) (see Table 3). The ET was expressed as percentage of infested plants with at least one egg mass (Paula-Moraes et al. 2011) and calculated using the mean number of eggs per egg mass determined previously.

\section{Results}

Egg Survivorship and Developmental Time in Laboratory and Field. In the laboratory, the time of western bean cutworm egg development decreased with the increase of temperature $(P=0.001)$ (Fig. 1). Egg hatch was $87.96 \%$ at $16^{\circ} \mathrm{C}, 93.36 \%$ at $25^{\circ} \mathrm{C}$, and $51.31 \%$ at $30^{\circ} \mathrm{C}$ (Fig. 1), and the overall mean egg hatch was $77 \%$ (Table 2).

At Concord (2008), under field conditions, the egg hatch mean was $86.6 \%$ (Table 2). During the period of the study, the lowest mean temperature mean was $19.5^{\circ} \mathrm{C}$, and the highest mean temperature mean was $30.7^{\circ} \mathrm{C}$. At Clay Center, the mean egg hatch was $78 \%$ (2008) and 77\% (2011) (Table 2). The highest and lowest mean temperatures at Clay Center in 2008 were 30.9 and $19.56^{\circ} \mathrm{C}$, respectively, and in 2011 the highest and lowest mean temperatures were 32.3 and $20.2^{\circ} \mathrm{C}$, respectively.
Based on 714 egg masses used in this and other studies described previously, the overall mean number of eggs per egg mass was 85.5 eggs (range, 2-345). The comparison between the egg mass sandwich infestation method and wild moths confined in pollination bags at Clay Center (2011) did not indicate significant differences in egg hatch for either silking $(P=$ $0.83)$ or VT $(P=0.54)$ stages. The overall mean egg hatch was $80 \%$ (Table 2).

Larval Survivorship in Field. The percentage of western bean cutworm larval survival $(\approx 20 \mathrm{~d}$ after egg infestation), based on total number of infested eggs, is presented for each year and location in Table 3. For 2009 and 2010, percentage of larval survival was calculated based on the total number of eggs infested. In 2008, the percentage of larval survival at Clay Center and Concord was calculated on the number considering the number of eggs hatched (Table 3 ). There was no significant effect of method of infestation (sandwich vs wild moths in large cages) in larval survival at Scottsbluff $(P=0.19)$.

Larval Consumption in Corn Field and Yield Impact in Field. The relationship between corn ear injury area (square centimeters) and level of western

Table 2. Egg survival of western bean cutworm in laboratory and on corn in the field

\begin{tabular}{lcc}
\hline \multicolumn{1}{c}{ Yr } & Total no. of eggs ${ }^{a}$ & $\begin{array}{c}\text { Egg hatch, } \\
\text { mean } \pm \text { SD }(\%)^{b}\end{array}$ \\
\hline $\begin{array}{l}\text { Laboratory } \\
\text { 2009 }\end{array}$ & 1,176 (34 egg masses) & $77.2 \pm 22.24$ \\
$\begin{array}{l}\text { Concord, NE } \\
\text { 2008 }\end{array}$ & 3,927 (76 egg masses) & $86.6 \pm 14.46$ \\
Clay Center, NE & 4,037 (73 egg masses) & $77.7 \pm 25.50$ \\
2008 & 1,828 (24 egg masses) & $76.9 \pm 24.46$ \\
2011 &
\end{tabular}

${ }^{a}$ Artificial infestation of egg mass sandwich method at Clay Center and Concord, 2008. Artificial infestation of western bean cutworm females inside pollination bags at three corn stages at Clay Center, 2011 .

${ }^{b}$ Laboratory egg hatch mean is an overall estimation for 16,25 , and $30^{\circ} \mathrm{C}$. At Clay Center in 2011, overall egg hatch mean at three corn stages (V18,VT, and silking). 
Table 3. Western bean cutworm larval survival on corn in the field at three locations in Nebraska

\begin{tabular}{lcr}
\hline \hline Yr & \% larval survival $^{a}$ & No. of larvae $^{c}$ \\
\hline Clay Center & & \\
2008 & $2.43(2.91)^{b}$ & 42 \\
2009 & 4.34 & 110 \\
2010 & 4.28 & 282 \\
Concord & & 71 \\
2008 & $4.23(4.83)^{b}$ & 42 \\
2009 & 1.51 & 240 \\
2010 & 5.40 & \\
Scottsbluff & & 480 \\
2008 & 12.82 & 152 \\
2009 & 4.47 & \\
\hline
\end{tabular}

${ }^{a}$ Larval survival percentage based on total number of eggs infested.

${ }^{b}$ Larval survival percentage based on total number of eggs hatched (Clay Center and Concord, 2008 only).

bean cutworm larval infestation in three ecoregions of Nebraska is presented on Table 4 . In most years, there was a significant linear relationship between corn injury and the level of western bean cutworm larval infestation. The overall mean of western bean cutworm injury/ear across all sites was $15.17 \mathrm{~cm}^{2}$ (4.96 $\mathrm{cm}^{2}[\mathrm{SEM}] ; N=11,966$ corn ears).

A significant linear relationship between corn yield (grams) and number of western bean cutworm per ear was only detected at Scottsbluff in $2008(\hat{y}=186.48$ [1.76 SEM] - 3.46 [1.46 SEM] $x)(P \leq 0.03)$. In other years and locations, there was a significant relationship between the number of the western bean cutworm number larvae and corn ear injury (Table 4); however, no relationship was detected between levels of western bean cutworm larvae with subsequent corn yield loss. This finding was presumably because of experimental problems (e.g., bird predation, Scottsbluff 2009; hail damage, Concord 2009) but also because of a general low larval survival across locations per year, resulting in low actual infestation levels.

In 2011, the direct infestation of corn with fourthinstar western bean cutworm eliminated the problems of early instar mortality (Table 3). There was a significant linear relationship between larval infestation and yield loss when corn was infested in blister and milk stages at Clay Center and when infested in blister stage at Concord (Table 5). In a generalized linear mixed model, the $R^{2}$ is undefined; therefore, the correlation between the observed and predicted values of corn ear weight was calculated for each data set (Fig. 2) to assess the fit of the model.

The overall means of larval injury at Clay Center were $12.46 \mathrm{~cm}^{2}$ (1.40 SEM) for corn infested in blister stage and $13.52 \mathrm{~cm}^{2}$ (0.91 SEM) for corn infested in milk stage. At Concord, the overall means of larval injury were $9.94 \mathrm{~cm}^{2}(0.64 \mathrm{SEM})$ and $7.98 \mathrm{~cm}^{2}$ (0.54 SEM) for corn in blister and milk stage, respectively.

Larval Consumption in Laboratory. In 2009, differences in injury area from western bean cutworm larvae were not detected $(P=0.30)$ when the corn ear was infested in blister or milk stage (small container method). The observed injury means were $13.25 \mathrm{~cm}^{2}$ (1.60 SEM) and $11.10 \mathrm{~cm}^{2}(1.10 \mathrm{SEM})$ when the corn ear was in blister and milk stage, respectively. There were no significant differences between injury of milk stage corn ear in the small container and big container $(P=0.09)$, and the mean of injury area for the whole corn ear (large container method) was $15.13 \mathrm{~cm}^{2}(0.98$ SEM). In 2011, the mean injury area with the whole corn ear infested in blister stage (large container method) was $16.87 \mathrm{~cm}^{2}$ (1.41 SEM).

EILs and ETs. Based on each statistically significant regression equation (Table 5), the yield losses per one western bean cutworm larva in Clay Center (2011) were 9.21 and $12.83 \mathrm{~g}$ per corn ear when the corn was infested in blister and milk stages, respectively (Table $5)$. In Concord (2011), the yield loss per one larva was $9.64 \mathrm{~g}$ when corn was infested with fourth-instar larvae in blister stage. The criterion of selection of slope for EIL calculation was based on the worst-case scenario of yield loss per insect, i.e., Clay Center corn infested in milk stage (Table 5). The correlation between observed and predicted values from each linear regression is presented in Fig. 2.

A range of crop values and management costs were used to calculate EILs. EILs are expressed in number of western bean cutworm larvae per ear,

Table 4. Linear regression equations for the relationship between corn ear injury area (square centimeters) and number of western bean larvae at three locations in Nebraska

\begin{tabular}{|c|c|c|c|c|c|}
\hline \multirow{2}{*}{$\mathrm{Yr}$} & \multirow{2}{*}{$\begin{array}{l}\text { Regression equation }(\hat{y}=\text { corn ear injury } \\
\text { area, } x=\text { no. of larvae per ear) }\end{array}$} & \multicolumn{2}{|c|}{ SEM } & \multirow{2}{*}{$P$} & \multirow{2}{*}{$N^{a}$} \\
\hline & & Slope & Intercept & & \\
\hline \multicolumn{6}{|c|}{ Clay Center } \\
\hline 2008 & $\hat{y}=0.89+3.67 x$ & 2.79 & 0.27 & 0.2055 & 1,362 \\
\hline 2009 & $\hat{y}=1.24+8.28 x$ & 0.38 & 1.83 & 0.0002 & 1,642 \\
\hline 2010 & $\hat{y}=0.68+5.22 x$ & 1.43 & 0.37 & 0.0015 & 1,093 \\
\hline \multicolumn{6}{|c|}{ Concord } \\
\hline 2008 & $\hat{y}=-0.04+9.93 x$ & 2.40 & 0.37 & 0.0006 & 1,401 \\
\hline 2009 & $\hat{y}=0.35+4.13 x$ & 1.53 & 0.17 & 0.0130 & 1,604 \\
\hline 2010 & $\hat{y}=2.74+8.60 x$ & 2.46 & 0.70 & 0.0025 & 1,769 \\
\hline \multicolumn{6}{|c|}{ Scottsbluff $b$} \\
\hline 2008 & $\hat{y}=0.61+2.15 x$ & 0.17 & 0.20 & $<0.0001$ & 1,330 \\
\hline 2009 & $\hat{y}=0.17+1.72 x$ & 0.08 & 0.24 & $<0.0001$ & 1,406 \\
\hline
\end{tabular}

${ }^{a}$ Number of evaluated corn ears (injury area measuring in square centimeters).

${ }^{b}$ Linear regression not tested in 2010 at Scottsbluff because of problems in the experimental area and limited number of replications. 
Table 5. Linear regression equations for the relationship between corn yield (grams per ear) and number of the western bean cutworm larvae by plant growth stage in two locations of Nebraska

\begin{tabular}{|c|c|c|c|c|}
\hline \multirow{2}{*}{ Plant stage } & \multirow{2}{*}{$\begin{array}{l}\text { Regression equation }(\hat{y}=\text { grain } \\
\left.\text { wt, } x=\text { no. of larvae }{ }^{a}\right)\end{array}$} & \multicolumn{2}{|c|}{ SEM } & \multirow{2}{*}{$P$} \\
\hline & & Slope & Intercept & \\
\hline \multicolumn{5}{|l|}{ Clay Center } \\
\hline Blister & $\hat{y}=244.29-9.21 x$ & 2.18 & 4.93 & 0.0003 \\
\hline Milk & $\hat{y}=226.84-12.83 x$ & 2.76 & 4.81 & 0.0002 \\
\hline \multicolumn{5}{|l|}{ Concord } \\
\hline Blister & $\hat{y}=217.16-9.64 x$ & 1.43 & 2.44 & $<0.0001$ \\
\hline Milk & $\hat{y}=191.55-3.54 x$ & 1.88 & 2.95 & 0.0754 \\
\hline
\end{tabular}

${ }^{a}$ Weight of grain in grams. Regression based on levels of western bean cutworm larval infestation: zero, one, two, and three.

and are presented in Table 6. EILs presented were calculated based on an insecticide application that gives 95\% control (Peairs et al. 2011). Cost of management reflects a range of actual price scenarios in Nebraska. Crop value considers a range of crop market price for the period of 2000-2011, including low, average, and high prices of corn. Besides the metric unit of dollar/hectare, the values are also converted in U.S. dollars per acre. The crop values also are converted in U.S. dollars per bushel. Based on $12.83 \mathrm{~g}$ of yield loss per ear infested with one western bean cutworm larva, conversion was done to kilograms per hectare considering 74,100 plants per ha $(30,000$ plants per acre) and resulted in a yield loss mean of $951 \mathrm{~kg} / \mathrm{ha}(15 \mathrm{bu} / \mathrm{acre})$.
The ETs were developed from EILs, expressed as the percentage of infested plants with at least one egg mass (Table 7). The ET was calculated based on the mean of 85 eggs per egg mass and again considering a plant population of 74,100 plants per ha (30,000 plants per acre). Larval survival was incorporated in the ET calculation considering the range of larval survival observed during $3 \mathrm{yr}$ across ecoregions of Nebraska (Table 3) and reports from consultants working in northeast Colorado, western Nebraska, and states east of the Missouri River.

\section{Discussion}

The study of western bean cutworm egg survivorship in the laboratory indicated that increasing tem-

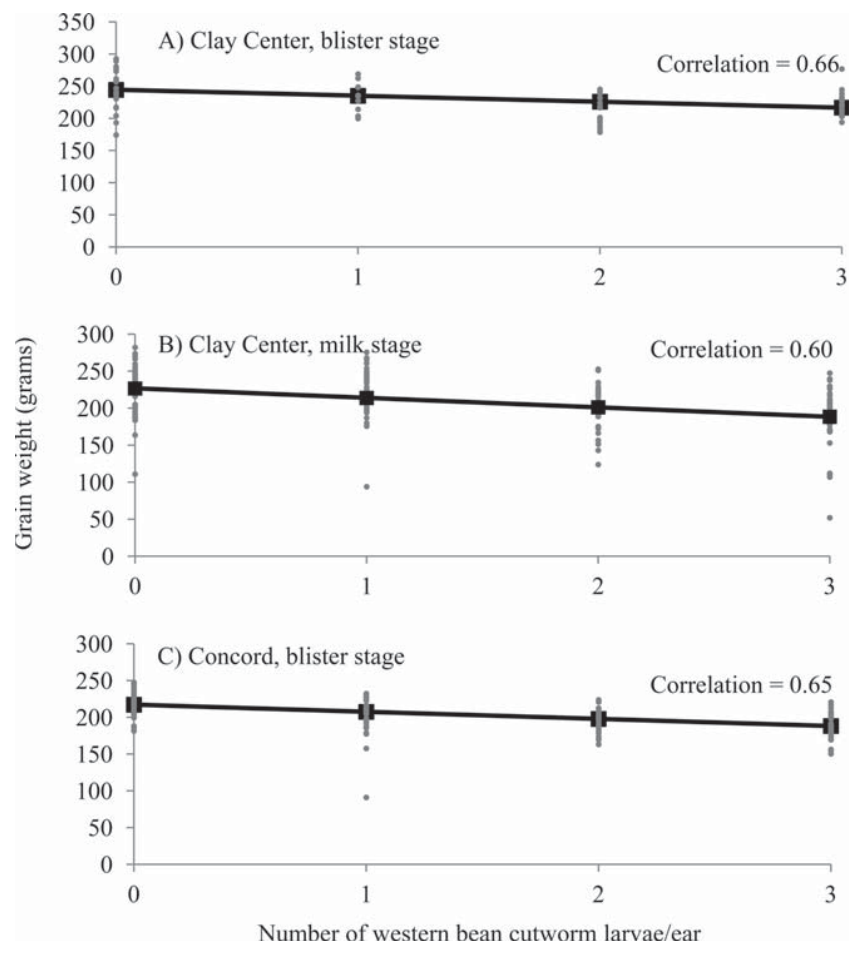

Fig. 2. Relationship between the number of western bean cutworm larvae and weight of grain (grams). Observed grain weight per ear from Clay Center (A and B), infested at blister and milk stages, and Concord (C), infested at blister stage, 2011. Predicted values from linear regressions (also see Table 5). As a check of the model fit, the correlations between predicted and observed values also are presented. 
Table 6. EILs expressed as larvae per ear for western bean cutworm

\begin{tabular}{|c|c|c|c|c|c|c|c|c|c|}
\hline & \multirow{2}{*}{ Crop value } & & \multicolumn{7}{|c|}{ Management cost, US\$/acre } \\
\hline & & & 4 & 6 & 8 & 10 & 12 & 14 & 16 \\
\hline & & & \multicolumn{7}{|c|}{ Management cost, US $\$$ ha } \\
\hline $\mathrm{US} \$ / \mathrm{bu}$ & US\$/acre & US $\$ /$ ha & 10 & 15 & 20 & 25 & 30 & 35 & 40 \\
\hline 3 & 660 & 1,630 & 0.50 & 0.75 & 0.99 & 1.24 & 1.49 & 1.74 & 1.99 \\
\hline 4 & 880 & 2,174 & 0.37 & 0.56 & 0.75 & 0.93 & 1.12 & 1.31 & 1.49 \\
\hline 5 & 1,100 & 2,717 & 0.30 & 0.45 & 0.60 & 0.75 & 0.90 & 1.04 & 1.19 \\
\hline 6 & 1,320 & 3,260 & 0.25 & 0.37 & 0.50 & 0.62 & 0.75 & 0.87 & 0.99 \\
\hline 7 & 1,540 & 3,804 & 0.21 & 0.32 & 0.43 & 0.53 & 0.64 & 0.75 & 0.85 \\
\hline
\end{tabular}

Conversions considering yield of $13,629.26 \mathrm{~kg} / \mathrm{ha}(220 \mathrm{bu} / \mathrm{acre}), 74,100$ plants per ha $(30,000$ plants per acre), and the range of corrected real market price of corn in December 2011.

perature decreases the time of the egg development. However, at $30^{\circ} \mathrm{C}$ there is a significant decrease in egg hatch (Fig. 1). The pattern of high heat negatively affecting egg hatch was not observed in the field study when egg hatch was evaluated in 2008 and 2011. The average temperatures during the summers of 2009 and 2011 surpassed $30^{\circ} \mathrm{C}$ during some parts of the day. However, this temperature was not constant all day, and it was probably variable in different parts of the plant canopy (Schoonkoven et al. 2005). The water vapor diffusion in the transpiration process on the corn leaf surface, in addition to leaf rotation with consequent decreasing of sun exposure, probably cre- ated a more favorable microclimate for the eggs (Smith 1954, Mani 1968). All of these factors probably contributed to decreased temperatures surrounding western bean cutworm eggs and consequently higher egg survival in the cornfield.

European corn borer egg mortality increased with high temperature in association with moisture stress (81\%) (Showers et al. 1978). However, the survivorship of European corn borer larvae was independent of oviposition and related to available feeding sites on host plant. In the current study, egg mortality was not found to be a critical factor in survival and establishment of the western bean cutworm on the host plant,

Table 7. Economic thresholds in percentage of infested plants with at least one western bean cutworm egg mass that considers larval survival

\begin{tabular}{|c|c|c|c|c|c|c|c|c|c|}
\hline & \multirow{2}{*}{ Crop value } & & \multicolumn{7}{|c|}{ Management cost, US\$/acre } \\
\hline & & & 4 & 6 & 8 & 10 & 12 & 14 & 16 \\
\hline & & & \multicolumn{7}{|c|}{ Management cost, US $\$ /$ ha } \\
\hline $\mathrm{US} \$ / \mathrm{bu}$ & US\$/acre & US\$/ha & 10 & 15 & 20 & 25 & 30 & 35 & 40 \\
\hline \multicolumn{10}{|l|}{$4 \%$ larval survival } \\
\hline 3 & 660 & 1,630 & 15 & 22 & 29 & 37 & 44 & 51 & 58 \\
\hline 4 & 880 & 2,174 & 11 & 16 & 22 & 27 & 33 & 38 & 44 \\
\hline 5 & 1,100 & 2,717 & 9 & 13 & 18 & 22 & 26 & 31 & 35 \\
\hline 6 & 1,320 & 3,260 & 7 & 11 & 15 & 18 & 22 & 26 & 29 \\
\hline 7 & 1,540 & 3,804 & 6 & 9 & 13 & 16 & 19 & 22 & 25 \\
\hline \multicolumn{10}{|l|}{$8 \%$ larval survival } \\
\hline 3 & 660 & 1,630 & 7 & 11 & 15 & 18 & 22 & 26 & 29 \\
\hline 4 & 880 & 2,174 & 5 & 8 & 11 & 14 & 16 & 19 & 22 \\
\hline 5 & 1,100 & 2,717 & 4 & 7 & 9 & 11 & 13 & 15 & 18 \\
\hline 6 & 1,320 & 3,260 & 4 & 5 & 7 & 9 & 11 & 13 & 15 \\
\hline 7 & 1,540 & 3,804 & 3 & 5 & 6 & 8 & 9 & 11 & 13 \\
\hline \multicolumn{10}{|l|}{$12 \%$ larval survival } \\
\hline 3 & 660 & 1,630 & 5 & 7 & 10 & 12 & 15 & 17 & 20 \\
\hline 4 & 880 & 2,174 & 4 & 6 & 7 & 9 & 11 & 13 & 15 \\
\hline 5 & 1,100 & 2,717 & 3 & 4 & 6 & 7 & 9 & 10 & 12 \\
\hline 6 & 1,320 & 3,260 & 2 & 4 & 5 & 6 & 7 & 9 & 10 \\
\hline 7 & 1,540 & 3,804 & 2 & 3 & 4 & 5 & 6 & 7 & 8 \\
\hline \multicolumn{10}{|l|}{$16 \%$ larval survival } \\
\hline 3 & 660 & 1,630 & 4 & 5 & 7 & 9 & 11 & 13 & 15 \\
\hline 4 & 880 & 2,174 & 3 & 4 & 5 & 7 & 8 & 10 & 11 \\
\hline 5 & 1,100 & 2,717 & 2 & 3 & 4 & 5 & 7 & 8 & 9 \\
\hline 6 & 1,320 & 3,260 & 2 & 3 & 4 & 5 & 5 & 6 & 7 \\
\hline 7 & 1,540 & 3,804 & 2 & 2 & 3 & 4 & 5 & 5 & 6 \\
\hline \multicolumn{10}{|l|}{$20 \%$ larval survival } \\
\hline 3 & 660 & 1,630 & 3 & 4 & 6 & 7 & 9 & 10 & 12 \\
\hline 4 & 880 & 2,174 & 2 & 3 & 4 & 5 & 7 & 8 & 9 \\
\hline 5 & 1,100 & 2,717 & 2 & 3 & 4 & 4 & 5 & 6 & 7 \\
\hline 6 & 1,320 & 3,260 & 1 & 2 & 3 & 4 & 4 & 5 & 6 \\
\hline 7 & 1,540 & 3,804 & 1 & 2 & 3 & 3 & 4 & 4 & 5 \\
\hline
\end{tabular}

Crop value calculated considering yield of $13,629.26 \mathrm{~kg} / \mathrm{ha}(220 \mathrm{bu} / \mathrm{acre}), 74,100$ plants per ha (30,000 plants per acre), and the range of corrected real market price of corn in December 2011 and the mean of 85 eggs per egg mass. 
and egg hatch was $\approx 80 \%$ across ecoregions of $\mathrm{Ne}$ braska.

Western bean cutworm infestation methods were tested in 2008 and 2009 in Scottsbluff. Larval recovery was compared between plots infested with large cages and plots that received egg mass sandwiches (both at the same $3 \%$ of level of infestation) (Table 1). At Clay Center in 2011, the infestation by deposition of the eggs from wild moths confined in pollination bags was compared with the egg mass sandwich method (Table 1). There were no significant differences observed in any comparison, so it can be concluded the artificial infestation methods used did not affect the results.

Western bean cutworm larval survival was evaluated in the field during $3 \mathrm{yr}$ across three ecoregions of Nebraska (Table 3) and incorporated in the final ET calculations (Table 7). The results indicated variability of larval survival across locations and years (Table 3). However, the very low larval survival observed (1.51\%) in Concord (2009) was not included in ET calculations because it was not representative. The higher larval survival of western bean cutworm observed at Scottsbluff in 2008 (12\%) (Table 3) was possibly related with the method of infestation. The large cages remained $\approx 2$ wk in the field which may have moderated the environmental conditions and provided protection against biocontrol agents. A $20 \%$ larval survival rate also was incorporated as an upper limit of larval survival and was based on anecdotal reports by consultants and entomologists of high larval survival in northeastern Colorado, Nebraska, and east of the Missouri River. In the central and eastern Corn Belt, higher humidity and overcast conditions could favor increased western bean cutworm larval survival.

Variable low larval survival was previously reported in the laboratory (Blickenstaff and Jolley 1982) when fresh corn tissue was used to rear larvae for $24 \mathrm{~d}$, with survival ranging from 19 to $40 \%$. Under field cage conditions, larval survival was estimated at $3.3 \%$ in Perkins County, NE (southwestern Nebraska) (Appel et al. 1993), although variation in larval survival also was detected at the same location. In an Iowa study investigating ear damage from western bean cutworm in transgenic corn hybrids, larval survival was estimated at $13 \%$ on susceptible hybrids and $1.3 \%$ in a corn hybrid expressing Bt protein Cryl F (Herculex I, Dow AgroSciences, Indianapolis, IN and Pioneer Hi-Bred International, Johnston, IA) (Eichenseer et al. 2008).

Larval mortality of Lepidoptera is reported to be high, especially in early instars (Zalucki et al. 2002). However, the range of mortality also is reported to be quite variable, depending on the species. For example, larval survival of European corn borer ranges from $\approx 15$ to $\approx 40 \%$ (Lee 1988) for second generation larvae (Wright 2007). Paula-Moraes (2012) demonstrated that the early larval stages are the most critical for the establishment of western bean cutworm on corn.

Oviposition and larval feeding behaviors are factors that can result in higher larval mortality (Zalucki et al.
2002). For western bean cutworm, oviposition is characterized by deposition of high numbers of small size eggs (average of 85 eggs per egg mass). This is an example of an "r strategy," characterized by a low expectation of survival for individuals of the species but with an investment that at least some will survive (MacArthur and Wilson 1967). Although mortality during the egg stage is not the most important survival factor for western bean cutworm (Table 2), the small size of the egg with few provisions represents a constraint in the establishment of the early larva, as it needs to quickly find a suitable feeding niche before starvation, desiccation, or predation. Moreover, the western bean cutworm larva has a mixed diet, feeding on different corn tissues (Hagen 1962, Seymour et al. 2004, Eichenseer et al. 2008). This mixed larval feeding behavior requires movement and exposure within the environment of the corn canopy that probably contributes to a higher level of larval mortality (Zalucki et al. 2002). Mortality of western bean cutworm is likely greatest before the larva becomes protected inside the ear at the beginning of the fourth instar (Seymour et al. 2004).

Corn stage probably plays a role in the establishment of western bean cutworm (pretassel stages providing the best nutrition and protection for early instars) (Paula-Moraes 2012), and this is probably why females select for a specific plant stage for oviposition (Blickenstaff 1979, Holtzer 1983, Eichenseer et al. 2008). However, in 2010 the infestation at Clay Center and Concord occurred near V18 (pretassel), and in Scottsbluff (2008) the infestation also occurred near V18. In both cases the overall larval survival was low ( $\approx 4 \%$ in the east and $12 \%$ in the west). Given that the pretassel stage should be ideal for early instar nutrition and protection, the low survival often observed indicates that factors other than plant stage must be important for larval survival. We believe the early instar movement that results from a mixed feeding behavior in addition to possible abiotic factors have significant impacts on larval survival (Paula-Moraes 2012). This also may be the reason survival is often greater in cage studies, as larvae exist in a buffered environment and are protected from predators, although this needs to be more fully investigated (Michel et al. 2010).

During the $3 \mathrm{yr}$ of egg mass infestation (Table 1), significant linear relationships between the number of the western bean cutworm larva and ear injury (Table 4) were detected. However, the infestation levels (Table 1) combined with the low larval survival (Table 2 ), resulted in larval population levels that were too low to detect a yield loss in experimental areas at Clay Center and Concord (eastern locations in Nebraska). Previous studies had the same problem (Appel 1991) and emphasized the need to improve the methodology of infestation and to determine egg and larval survival under field conditions. Egg and larval survival were characterized in the current study (Tables 2 and 3) based on several attempts to improve the field methodology (Table 1), but survival was consistently low, which we believe to be a characteristic of the species. 
Usable data related to actual corn yield loss per insect under field conditions at Clay Center and Concord that were only obtained when corn ears were directly infested in 2011 with fourth-instar larvae, eliminated early instar mortality factors.

Another complexity in describing the relationship between larval ear injury and yield loss is the type of injury caused by western bean cutworm. This insect causes direct injury (Pedigo et al. 1986) to the corn ear, predominantly with ear tip feeding. Indirect estimation of yield loss has been done by weighing a corresponding number of the kernels injured (Appel 1991, Dorhout 2007, Eichenseer et al. 2008), but this does not account for indirect effects of development of uninjured ear kernels.

Reports of western bean cutworm damage are quite variable in the literature, and also in this research, where yield loss per larvae varied from 9.21 to $12.83 \mathrm{~g}$ per larva (Table 5). There are anecdotal reports of late-instar movement in and out of the ear, possibly influenced by environment, but this is not well documented. This movement, coupled with feeding on different corn tissues, likely contributes to the observed variability. Regardless, because of this variability, the EIL calculations were based on the worst-case scenario of yield loss per larva (12.83 g per insect) (Table 5).

In the current study, corn injury from one western bean cutworm larva was measured (square centimeters) in the laboratory and in the field. The overall mean injury area in the field during 2008-2010 was $15.17 \mathrm{~cm}^{2}$ (calculated from 11,966 corn ears). This injury is close to the overall mean observed in the 2009 $\left(13.43 \mathrm{~cm}^{2}, 0.74 \mathrm{SEM}\right)$, and the 2011 laboratory studies $\left(16.87 \mathrm{~cm}^{2}\right)$. However, the yield loss used for EIL calculation was based on the linear relationship between weight of corn yield loss of the ear (kilograms per ear) in four levels of larval infestation (zero, one, two, and three larvae per ear) in 2011. This decision was based on the difficulty in obtaining an accurate estimating of the amount of injured kernels in the ear tip, and how much these injured kernels contribute to the yield.

The overall mean yield loss per western bean cutworm larva observed from the 2011 study is 936.62 $\mathrm{kg} / \mathrm{ha}(14.93 \mathrm{bu} / \mathrm{acre})$, based on 74,100 plants per ha. This is different than previously reported yield loss, others of which were estimated by indirect methods (e.g., Appel et al. 1993). However, because this study used the yield loss regression that considered the actual larval injury and resultant yield loss, the problems associated with estimation of the number of injured kernels in the ear tip were minimized.

The ET calculations incorporated the average number of the eggs per egg mass and larval survival (Table 7). An average of 85 eggs per egg mass estimated in this study was higher than 64 eggs per egg mass reported previously (Blickenstaff 1979); however, the average number of eggs estimated in this study was based on 714 egg masses collected over 4 yr.

The incorporation of larval survival represents a refinement of the ET (Higley and Peterson 2009).
First, it allows savings in management because it accounts for the actual population of the injurious life stage of the species and the effect of mortality factors (Ostlie and Pedigo 1987). Second, using the percentage of plants infested with at least one egg mass allows for the timely implementation of management tactics (Bode and Calvin 1990, Appel et al. 1993, Wright 2007, Michel et al. 2010, Paula-Moraes et al. 2011).

The nominal action thresholds previously proposed for western bean cutworm on corn $(4,8$, and $20 \%$ of plants infested with an egg mass) (Seymour et al. 2004, Peairs 2006, Rice 2007, Cullen and Jyuotika 2008) are encompassed by the calculated ETs in several scenarios that include larval survival (Table 7). The action threshold of $20 \%$ of plants infested with an egg mass is least represented in the various scenarios; however, this threshold was suggested when corn prices were low (e.g., <US\$2.50/bu) and was recommended when egg masses were present during mid-milk stage corn (Rice 2007), a relatively rare occurrence because western bean cutworm moths prefer late whorl-stage corn for oviposition (Hagen 1962, Blickenstaff 1979, Holtzer 1983, Seymour et al. 2004, Eichenseer et al. 2008). The action thresholds of 4 and $8 \%$ of plants infested with an egg mass are well represented across scenarios, except for the $4 \%$ survival scenario. However, larval survival is often reported as $>4 \%$ (e.g., Table 3; Eichenseer et al. 2008), so there is a risk of making the decision to not treat when treatment is warranted when using economic thresholds based on $4 \%$ larval survival. Nominal action thresholds are set to reduce this risk, and indeed, we would suggest that unless larval survival is well understood for a specific situation, economic thresholds based on larval survival of $>4 \%$ should be used.

More local information about larval survival and late-instar behavior will enable further adjustments to ETs for western bean cutworm (Michel et al. 2010) across the Corn Belt. Characterization of larval survival and feeding behavior also will be important when considering Bt corn hybrids expressing $\mathrm{Bt}$ toxins toxic to western bean cutworm, but with incomplete control that may require additional management, as observed for cotton bollworm (Naranjo et al. 2008).

\section{Acknowledgments}

We thank Logan Dana, Terry DeVries, and Rick Patrick for technical support, USDA North Central Integrated Pest Management Program Proposal N. 2008-34103, and Embrapa Agrofuturo, Brazil.

\section{References Cited}

Appel, L. L. 1991. Damage in field corn (Zea mays (L.)) caused by Loxagrotis albiscosta (Smith). M.S. thesis, University of Nebraska-Lincoln.

Appel, L. L., R. J. Wright, and J. B. Campbell. 1993. Economic injury levels for western bean cutworm, Loxagrotis albicosta (Smith) (Lepidoptera: Noctuidae), larvae in field corn. J. Kans. Entomol. Soc. 66: 434-438. 
Barrigossi, J.A.F., G. L. Hein, and L. G. Higley. 2003. Economic injury levels and sequential sampling plans for Mexican bean beetle (Coleoptera: Coccinellidae) on dry beans. J. Econ. Entomol. 96: 1160-1167.

Blickenstaff, C. C. 1979. History and biology of the western bean cutworm in southern Idaho, 1942-1977. Univ. Idaho Agric. Exp. Stn. Bull. 592.

Blickenstaff, C. C., and P. M. Jolley. 1982. Host plants of western bean cutworm. Environ. Entomol. 11: 421-425.

Bode, W. M., and D. D. Calvin. 1990. Yield-loss relationship and economic injury levels for European corn borer (Lepidoptera: Pyralidae) populations infesting Pennsylvania field corn). J. Econ. Entomol. 83: 1595-1603.

Catangui, M. A., and R. K. Berg. 2006. Western bean cutworm, Striacosta albicosta (Smith) (Lepidoptera: Noctuidae), as a potential pest of transgenic Cry $1 \mathrm{Ab}$ Bacillus thuringiensis corn hybrids in South Dakota. Environ. Entomol. 35: 1439-1452.

Chapman, S. S., J. M. Omernik, J. A. Freeouf, D. G. Huggins, J. R. McCauley, C. C. Freeman, G. Steinauer, R. T. Angelo, and R. L. Schlepp. 2001. Ecoregions of Nebraska and Kansas (color poster with map, descriptive text, summary tables and photographs; map scale 1:1,950,000). U.S Geological Survey, Reston, VA.

Cullen, E., and J. Jyuotika. 2008. Western bean cutworm: a pest of sweet corn. A3856, University of Wisconsin Extension, Cooperative Extension. (http://learningstore. uwex.edu/pdf/A3856.pdf).

DiFonzo, C. D., and R. Hammond. 2008. Range expansion of western bean cutworm, Striacosta albicosta (Noctuidae), into Michigan and Ohio. Crop Mgt. doi:10.1094/ CM-2008-0519-01-B. (http://msuent.com/assets/DiFonzo HammondWBC.pdf).

Dorhout, D. L. 2007. Ecological and behavioral studies of the western bean cutworm (Lepidoptera: Noctuidae) in corn. M.S. thesis, Iowa State University, Ames.

Dorhout, D. L., and M. E. Rice. 2004. First report of western bean cutworm, Richia albicosta (Noctuidae) in Illinois and Missouri. (http://www.plantmanagementnetwork. $\mathrm{org} / \mathrm{pub} / \mathrm{cm} / \mathrm{brief} / 2004 /$ cutworm).

Douglass, J. R., J. W. Ingram, K. E. Gibson, and W. E. Peay. 1957. The western bean cutworm as a pest of corn in Idaho. J. Econ. Entomol. 50: 543-5.

Eichenseer, H., R. Strohbehn, and J. Burks. 2008. Frequency and severity of western bean cutworm (Lepidoptera: Noctuidae) ear damage in transgenic corn hybrids expressing different Bacillus thuringiensis cry toxins. J. Econ. Entomol. 101: 555-563.

Hagen, A. F. 1962. The biology and control of the western bean cutworm in dent corn in Nebraska. J. Econ. Entomol. 55: 628-631.

Hagen, A. F. 1976. A fourteen-year summary of light trap catches of the western bean cutworm in Nebraska Loxagrotis albicosta (Smith) (Lepidoptera: Noctuidae). J. Kans. Entomol. Soc. 49: 537-540.

Higley, L. G., and R.K.D. Peterson. 2009. Economic decision rules for IPM. In E. B. Radcliffe, W. D. Hutchison, and R. E. Cancelado (eds.), Integrated pest management: concepts, tactics, strategies and case studies. Cambridge University Press, Cambridge, United Kingdom.

Holtzer, T. O. 1983. Distribution of western bean cutworm eggs among short-, mid, and long-season corn hybrids planted on different dates. Environ. Entomol. 12: 13751379.

Klein, R. N., and R. K. Wilson. 2012. Nebraska crop budgets 2011. Extension Circular 972, University of Nebraska Extension. (http://www.ianrpubs.unl.edu/epublic/live/ ec872/build/ec872.pdf).
Lee, D. A. 1988. Factors affecting mortality of the European corn borer, Ostrinia nubilalis (Hübner), in Alberta. Can. Entomol. 120: 841-853.

MacArthur, R. H., and E. O. Wilson. 1967. The theory of island biogeography. Princeton University Press, Princeton, NJ.

Mani, M. S. 1968. Ecology and biogeography of high altitude insects. Springer, New York.

Michel, A. P., C. H. Krupke, T. S. Baute, and C. D. DiFonzo. 2010. Ecology and management of the western bean cutworm (Lepidoptera: Noctuidae) in corn and dry beans. J. Integr. Pest Manag. 1: A1-A10.

Naranjo, S. E., J. R. Ruberson, H. C. Sharma, L. Wilson, and K. Wu. 2008. The present and future role of insect-resistant genetically modified cotton in IPM, pp. 159-194. In J. Romeis, A. M. Shelton, and G. G. Kennedy (eds.), Integration of insect-resistant genetically modified crops within IPM programs. Springer, Amsterdam, The Netherlands.

O'Rourke, P. K., and W. D. Hutchison. 2000. First report of the western bean cutworm Richia albicosta (Smith) (Lepidoptera: Noctuidae), in Minnesota corn. J. Agric. Urban Entomol. 17: 213-217.

Ostlie, K. R., and L. P. Pedigo. 1987. Incorporating pest survivorship into economic thresholds. Bull. Entomol. Soc. Am 1987. 33: 98-102.

Paula-Moraes, S. V. 2012. Ecology and integrated pest management of western bean cutworm Striacosta albicosta (Smith) (Lepidoptera: Noctuidae) in field corn. Ph.D. dissertation, University of Nebraska-Lincoln.

Paula-Moraes, S. V., E. C. Burkness, T. E. Hunt, R. J. Wright, G. L. Hein, and W. D. Hutchison. 2011. Cost-effective binomial sequential sampling of western bean cutworm, Striacosta albicosta (Lepidoptera: Noctuidae), egg masses in corn. J. Econ. Entomol. 104: 1900-1908.

Peairs, F. B., J. B. Rudolph, and T. L. Randolph. 2011. 2010 Colorado field crop insect management research and demonstration trials. Colo. State Univ. Agric. Exp. Stn. Tech. Rep. TR11-03.

Peairs, F. B. 2006. Western bean cutworm: characteristics and management in corn and dry beans. Colorado State University Extension. (http://www.ext.colostate.edu/ pubs/insect/05538.html).

Pedigo, L. P., and M. E. Rice. 2009. Entomology and pest management. Prentice Hall, New Jersey.

Pedigo, L. P., S. H. Hutchins, and L. G. Higley. 1986. Economic injury levels in theory and practice. Annu. Rev. Entomol. 31: 341-368.

Rice, M. E. 2007. Economic thresholds for western bean cutworms. Iowa State University Extension, Ames, IA. (http:// www.ipm.iastate.edu/ipm/icm/2007/7-2/wbcthresholds. html).

Rice, M. E. 2006. Eastern movement of the western bean cutworm into Indiana and Ohio. Proceedings: Indiana CCA Conference, Indianapolis, IN.

Ritchie, S. E., J. J. Hanway, and G. O. Benson. 1993. How a corn plant develops. Iowa Coop. Ext. Serv. Spec. Rep. 48.

SAS Institute. 2009. SAS user's guide: statistics, version. 9.1.3. SAS Institute, Cary, NC.

Schoonkoven, L. M., J.J.A. Van Loon, and M. Dicke-Smith. 2005. Insect-plant biology. University of Oxford, Oxford, United Kingdom.

Seymour, R. C., G. L. Hein, R. J. Wright, and J. B. Campbell. 2004. Western bean cutworm in corn and dry beans. NebGuide G1359. Nebraska Cooperative Extension, Lincoln, NE.

Showers, W. B., M. B. de Rozari, G. L. Reed, and R. H. Shaw. 1978. Temperature-related climatic effects on 
survivorship of the European corn borer. Environ. Entomol. 7: 717-723.

Smith, R.F. 1954. The importance of the microenvironment in insect ecology. J. Econ. Entomol. 47: 205-210.

Stern, M., R. F. Smith, R. van den Bosch, and K. S. Hagen. 1959. The integrated control concept. Hilgardia 29: 330-350.

Tooker, J. F., and S. J. Fleischer. 2010. First report of western bean cutworm. (Striacosta albicosta) in Pennsylvania. Crop Manag. doi: http://dx.doi.org/10.1094/CM-2010-0616-01RS.
Wright, R. J. 2007. Second generation European corn borer scouting and treatments decisions. NebGuide G1783. University of Nebraska Extension, Lincoln, NE.

Zalucki, M. P., A. R. Clarke, and S. B. Malcom. 2002. Ecology and behavior of first instar larval lepidoptera. Annu. Rev. Entomol. 47: 361-393.

Received 19 October 2012; accepted 20 February 2013. 